\title{
PROGRAM EDUKASI LINGKUNGAN HIDUP BAGI SISWA RA UNTUK MEMAHAMKAN KONSEP "KANG PISMAN" MELALUI KEGIATAN BERMAIN
}

\author{
Dede Trie Kurniawan $^{* 1)}$,Sri Maryanti ${ }^{2}$, Astri Yuliawati $^{3)}$, Nailah Tresnawati ${ }^{4)}$ \\ 1),4) PGSD FKIP Universitas Swadaya Gunung Jati Cirebon, Email : dhe3kurniawan@gmail.com \\ 2), 3) Program Studi Pendidikan Biologi FTK UIN Sunan Gunung Djati, Bandung. Email : sri.maryanti@uinsgd.ac.id
}

\begin{abstract}
Abstrak
Sampah adalah masalah dunia. Perlu sebuah aksi pengurangan sampah dari hulu dengan konsep 3R (Reduce, Reuse, Recycle). Berbagai macam sampah sebagai hasil samping kegiatan manusia terus diproduksi setiap harinya, maka Perlu adanya pembenahan budaya bagi masyarakat indonesia mengenai pengelolaan sampah plastik. Penanaman nilai kebersihan lingkungan terhadap anak sejak dini sangatlah penting, karena Anak-anak yang masih dalam tahap perkembangan berada pada proses imitasi dengan melihat apa yang orang dewasa di sekitarnya lakukan. Perlu dilakukan kegiatan edukasi lingkungan hidup mengenai gaya hidup bijak dalam penggunaan plastik melalui kegiatan mewarnai tas pakai ulang (Totebag) bagi anak anak. Kegiatan ini dimaksudkan sebagai wahana edukasi lingkungan hidup dalam menanamkan sebuah gaya hidup "Zero Waste" melalui moto kang pisman (kurangi, pisahkan dan manfaatkan) kepada siswa RA disalah satu RA Kabupaten Bandung. Secara Garis besar Pelaksanaakan kegiatan ini dapat dikategorikan sukses dan berjalan dengan baik. Hal ini dapat ditunjukan dengan sebagian besar pemberian respon dari peserta siswa RA, Guru dan Kepala sekolah RA yang mengungkapkan bahwa kegiatan ini sangat baik karena dapat memberikan manfaat dan memperluas wawasan mereka selaku anggota masyarakat yang di lingkungan mereka terkenal selalu rawan kejadian banjir akibat penanganan sampah plastik yang tidak baik.
\end{abstract}

Kata Kunci: Pendidikan Lingkungan Hidup, Pendidikan Anak Usia Dini, Diet Kantong Plastik

\section{Abstract}

Garbage is a world problem. Need an action to reduce waste from upstream with the 3R concept (Reduce, Reuse, Recycle). Various types of waste as a by-product of human activities are continuously produced every day, so there needs to be a cultural improvement for the Indonesian people regarding the management of plastic waste. Planting the value of environmental hygiene for children from an early age is very important, because children who are still in the development stage are in the imitation process by seeing what the adults around them do. It is necessary to conduct environmental education activities regarding wise lifestyles in the use of plastic through activities of coloring a reuse bag (Totebag) for children. This activity is intended as a vehicle for environmental education in instilling a "Zero Waste" lifestyle through the motto of Pisman (reducing, separating and utilizing) for RA students in one of the RA of Bandung Regency. Broadly speaking, the implementation of this activity can be categorized as successful and running well. This can be shown by most of the response from participants of RA students, Teachers and Principals of RA who revealed that this activity is very good because it can provide benefits and broaden their horizons as members of the community who are known to be prone to flooding due to handling plastic waste that is not good.

Keywords: Environmental Education, Early Childhood Education, Plastic Bag Diet

\section{PENDAHULUAN}

Sampah adalah masalah dunia. Tidak hanya di kota-kota besar di dunia, tapi juga di Indonesia. Kalau kita hanya fokus pada penanganan di akhir, hanya masalah waktu untuk meledak. Justru yang penting adalah aksi pengurangan sampah dari hulu dengan konsep 3R (Reduce, Reuse, Recycle). Masalah sampah seakan menjadi persoalan yang terus menyita energi untuk dapat diselesaikan. Berbagai macam sampah sebagai hasil samping kegiatan manusia terus diproduksi setiap harinya. Di pasar, industri, perkantoran, rumah tangga, bahkan di sekolah tidak luput dengan masalah sampah. Hal ini disebabkan oleh kebiasaan masyarakat membuang sampah sembarangan yang sulit dihilangkan.Permasalahan mendasar dari masyarakat dalam membuang sampah sembarangan ini disebabkan karena selama ini masyarakat terlanjur berperilaku atau memiliki kebiasaan yang tidak benar dalam mengelola sampah.

Dewasa ini plastik merupakan sesuatu yang sudah tidak asing lagi di telinga kita, bahan plastik disukai karena memiliki sifat praktis, mudah, dan kedap air, hal ini sesuai 
dengan mobilitas kehidupan orang modern. Tidak terkecuali juga pada kantong plastik belanjaan sekali pakai yang sering kali kita buang begitu saja sehabis kita pakai, kantong plastik sekali pakai yang kita gunakan juga tidak semuanya terbuat dari bahan kimia yang baik, dan sehat untuk diri dan lingkungan kita. Beberapa jenis kantong plastik yang kita gunakan justru sangat berbahaya bagi lingkungan dan kesehatan kita, terutama kantongkantong plastik sekali pakai yang terbuat dari bahan daur ulang plastik lainnya yang tidak jelas riwayat penggunaannya, plastik seperti ini bisa saja berasal dari bekas wadah limbah berbahaya seperti pestisida dan logam berat, limbah rumah sakit atau kotoran hewan, yang lebih menakutkan proses daur ulang kantong plastik ini kerap menggunakan bahan kimia yang berbahaya. Akibatnya tidak hanya bagi kesehatan kita melainkan bagi lingkungan kita juga.

Jenis plastik seperti ini sangat berbahaya bagi kesehatan karena jika dipakai untuk membungkus makanan bahan kimia yang terdapat pada kantong plastik sangat mudah terdegradasi jika terkena panas dan akan mengenai makanan yang terdapat di dalam kantong plastik tersebut, bagi lingkungan kita plastik seperti ini juga sangat berbahaya karena plastik seperti ini membutuhkan waktu puluhan sampai ratusan tahun untuk plastik ini dapat terurai dengan baik dengan lingkungan kita sehingga menyebabkan terjadinya pencemaran lingkungan, penggunaan plastik yang terus bertambah setiap harinya menyebabkan sampah plastik ini semakin hari semakin menumpuk yang akhirnya akan tertimbun dan menjadi gunung sampah yang kemudian sebagai solusinya sampah plastik ini dibakar, akan tetapi kantong plastik ini tetap tidak akan terurai dengan baik sekalipun dibakar, melainkan akan menghasilkan gas dioksin yang akan menjadi racun bagi mahluk hidup dan merusak lingkungan kita serta menimbulkan efek pemanasan global. Jika dibuang di sembarang tempat seperti solokan atau sungai plastik ini juga akan menyumbat saluran air dan menyebabkan pencemaran air serta banjir.

Plastik seperti ini banyak sekali beredar di pasar-pasar tradisional, pedagang asongan pinggir jalan dan di beberapa pertokoan. Plastik seperti ini banyak sekali berputar dan di konsumsi oleh masyarakat dengan kelas menengah kebawah yang cenderung memiliki tingkat pendidikan dan taraf kehidupan yang rendah, hal itu tentu berpengaruh pada perilaku mereka, banyak dari mereka yang tidak mengetahui bahaya dan ancaman apa yang akan terjadi jika mereka terus menerus menggunakan kantong plastik dengan kualitas sangat buruk yang kemudian setelah mereka pergunakan mereka akan membuangnya di sembarang tempat tanpa memikirkan waktu yang di butuhkan untuk plastik tersebut untuk terurai maksimal sehingga semakin hari sampah-sampah plastik tersebut semakin bertambah, menumpuk dan mencemari lingkungan kita, bahkan banyak juga dari mereka yang menggunakan plastik tersebut sampai berulangkali.

Hal ini merupakan sebuah masalah besar bagi kita, karena sebagian besar dari masyarakat bangsa Indonesia ini adalah mereka-mereka yang memiliki tingkat dan taraf kehidupan yang rendah dan mereka inilah yang merupakan konsumen dan pengguna terbesar dari kantong plastik yang tidak ramah lingkungan, hal ini sudah menjadi sebuah kebiasaan dan gaya hidup bagi mereka. Ini merupakan ancaman besar bagi bangsa kita karena apabila tidak segera diatasi, lingkungan kita akan tertutupi, rusak, dan terkontaminasi oleh plastik tersebut yang juga akan memberikan dampak buruk juga bagi ekosistem yang ada didalamnya.

Sekolah sebagai tempat berkumpulnya banyak orang dapat menjadi penghasil sampah terbesar selain pasar, rumah tangga, industri dan perkantoran. Secara umum sampah dapat dipisahkan menjadi :

Sampah organik atau mudah busuk berasal dari: sisa makanan, sisa sayuran dan kulit buah-buahan, sisa ikan dan daging, sampah kebun (rumput, daun dan ranting),

Sampah anorganik atau tidak mudah busuk berupa : kertas, kayu, kain, kaca, logam,plastik, karet dan tanah.Sampah yang dihasilkan sekolah kebanyakan adalah jenis sampah kering dan hanya sedikit sampah basah.

Sampah kering yang dihasilkan kebanyakan berupa kertas, plastik dansedikit logam. Sedangkan sampah basah berasal dari guguran daun pohon, sisa makanan dan daun pisang pembungkus makanan.(Nasih, 2010)

Pemilahan sampah merupakan perlakuan awal dalam penanganan sampah dengan memisahkan paling sedikit menjadi tiga jenis sampah, yaitu: (1) Sampah yang mudah terurai, meliputi sampah yang berasal dari tumbuhan, hewan, dan/atau bagian yang dapat terurai oleh makhluk hidup lainnya dan/atau mikroorganisme; (2) Sampah yang dapat digunakan kembali dan sampah yang dapat didaur ulang; dan (3) Sampah yang mengandung bahan berbahaya dan beracun. Sampah yang telah terpilah tersebut harus ditempatkan atau ditampung dalam wadah sampah berdasarkan jenis sampah Pemilahan dan penempatan sampah pada tempatnya merupakan tahapan paling utama yang memungkinkan untuk diterapkan pada usia anak-anak Sekolah dasar sebagai bentuk pembelajaran untuk menanamkan nilai-nilai kebersihan lingkungan sejak dini.

Penanaman nilai kebersihan lingkungan terhadap anak sejak dini sangatlah penting, karena anak merupakan generasi penerus bangsa yang sebaiknya telah dibekali oleh orang dewasa atau guru mengenai hal-hal yang dapat menjaga keberlangsungan sebuah bangsa dalam hal ini salah satunya adalah dengan menjaga lingkungan bersih. 
Anak-anak yang masih dalam tahap perkembangan berada pada proses imitasi dengan melihat apa yang orang dewasa di sekitarnya lakukan. (Gunarsa, 2004) Demikian juga dalam hal membuang sampah. Mencontohkan membuang sampah pada tempatnya oleh orang dewasa kepada anak usia dini merupakan salah satu upaya mengurangi kebiasaan buruk yang dapat menyelamatkan lingkungan.

Anak pada usia dini sangatlah mudah untuk diberi pengetahuan atau diarahkan yang lebih baik, dalam hal ini yaitu untuk menjaga kebersihan lingkungan sekolahnya. Untuk menjaga kebersihan lingkungan sekolahnya ini, anak harus dibiasakan membuang sampah pada tempatnya. Kesadaran anak untuk membuang sampah pada tempatnya menjadi salah satu faktor penting dalam pembelajaran kesehatan lingkungan bersih. Pengelolaan sampah tidak semata-mata menggunakan teknologi canggih, tetapi lebih membutuhkan perubahan dan pembentukan perilaku individu. Untuk pembentukan perilaku individu dalam mengelola sampah yang benar perlu ditanamkan sejak usia dini, yang merupakan usia emas pembentukan perilaku. Pembentukan perilaku pada usia ini lebih mudah dan lebih terlihat hasilnya daripada usia berikutnya. Pembentukan perilaku mengelola sampah sejak usia dini ini dapat dimulai dari pembentukan kebiasaan memilah dan menempatkan sampah pada tempatnya. Apabila kebiasaan memilah dan menempatkan sampah pada tempatnya sudah tertanam sejak usia dini, selanjutnya diharapkan akan terus terbawa hingga perjalanan usia selanjutnya, yang pada gilirannya akan lebih mudah secara bersama-sama dalam mengelola sampah dan menciptakan lingkungan yang bersih dan sehat.

Penggunaan tas pakai ulang merupakan salah satu usaha yang bisa diterapkan masyarakat ketika berbelanja, seperti kembali lagi ke jaman dahulu dimana para ibu tidak pernah lupa membawa kantong belanja ketika berbelanja ke pasar dan ketika pembungkus tahu atau bahkan daging hanya menggunakan daun pisang yang dilipat apik secara khusus dan bukan plastik berukuran 24 x 32 x $3,8 \mathrm{~cm}$. Akan tetapi kini masyarakat moderen menuntut hal yang bersifat praktis, ringkas dan sederhana. Para ibu sudah mulai meninggalkan cara-cara konvensional, beralih ke gaya hidup yang konsumtif, sebagian darinya hanya demi gengsi dan sebagian yang lainnya beralih karena sudah menjadi kebiasaan untuk "terfasilitasi" kantong plastik gratis dimana-mana.

Dari latar belakang yang telah dipaparkan, maka perlu dilakukan kegiatan edukasi lingkungan hidup mengenai gaya hidup bijak dalam penggunaan plastik melalui kegiatan mewarnai tas pakai ulang (Totebag) bagi anak anak. Kegiatan ini dimaksudkan sebagai wahana edukasi lingkungan hidup dalam menanamkan sebuah gaya hidup
"Zero Waste" kepada siswa RA disalah satu RA Kabupaten Bandung. Melalui kegiatan ini diharpkan guru - guru dan siswa dapat lebih eksplorasi kreatfitas pengajaranya, menyenangi, siap berpartsipasi dalam pendidikan lingkungan hidup bagi anak sedari dini di pembelajaran IPA menjadi menyenangkan dalam memahami konten fisika/biologi mengenai lingkungan hidup.

\section{METODOLOGI PENGABDIAN}

Penelitian ini dilakukan dengan beberapa tahap yaitu seperti pada gambar 1 .

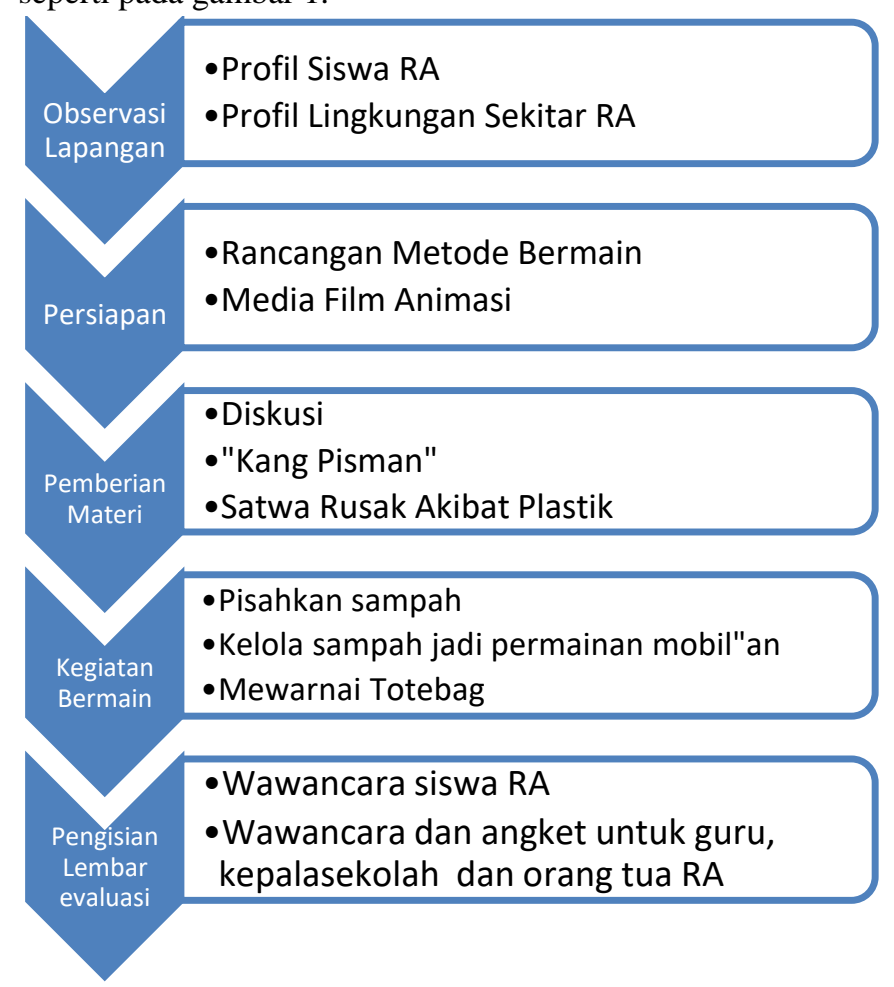

Gambar 1. Bagan Penelitian

Penelitian yang dilakukan berupa kegiatan pengabdian dengan bentuk program edukasi untuk siswa RA mengenai pendidikan lingkungan hidup dengan tema diet kantong plastik dengan moto "Kang Pisman" di RA Atta'Awun, Kecamatan Cileunyi Kabupaten Bandung. Selama kegiatan dilakukan pengamatan terkait aktifitas belajar peserta didik dengan indikator meliputi keaktifan dan pemahaman mengenai konsep "kang pisman". Kegiatan pendahuluan berupa observasi lapangan dengan melihat secara langsung kondisi subjek pelatihan, dengan observasi lapangan. Observasi lapangan dilaksanakan dengan mewawancarai Kepala Sekolah terkait keadaan peserta didik. Tahap Persiapan dilakukan dengan pembuatan dan uji coba Animasi Film dan Kegiatan bermain mewarnai totebag. Tahap pelaksanakan dilaksanakan dengan acara tatap muka, diskusi dan praktek kegiatan di kelas dan lapangan. Pertemuan tatap muka menggunakan metode ceramah, demonstrasi serta praktik terbimbing dengan metode bermain dilakukan 
dengan berbantuan media laptop, proyektor dan bahan bermain mewarnai " $\quad$ totebag” yang telah disiapkan. Berdasarkan rencana kegiatan yang telah disusun maka target luaran yang diharapkan setelah pelaksanaan program pelatihan ini adalah siswa-siswa SD kelas rendah dan anak usia dini mendapatkan wawasan pengetahuan dan pemberian pemahaman bagi siswa mengenai permasalahan sampah plastik dan turut serta berpartisipasi dalam program pemerintah berupa Diet Kantong plastik sebagai upaya mengurang penggunaan plastik di indonesia dengan membuat Totebag dari media yang sederhana dan digambar sesuai selera siswa agar menarik. Selain itu melalui kegiatan program pengabdian edukasi ini dapat menjadi sebuah stimulan awal untuk membuat kelompok kepeminatan pendidikan lingkungan hidup sebagai wahana ekstrakurikuler di sekolah dasar yang menjadi objek pengabdian. Dan Bila Sudah terbentuk kelompok keminatan ini akan dibuat program pendampingan bagi guru yang ditugaskan sebagai pembina ekstrakurikuler ini

\section{HASIL DAN PEMBAHASAN}

Kegiatan ini dimaksudkan untuk memberikan pengetahuan dan pemahaman atas permasalahan sampah plastik dan mengajak untuk dapat berpartsipasi dalam kegiatan "diet kantong plastik" yang sedang digalangkan oleh pemerintah kota bandung dengan slogan "kang pisman" nya. Melalui kegiatan program pengabdian edukasi ini diharapkan dapat menjadi wadah pengamalan ilmu dan pembelajaran dari bidang kepakaran dosen yang dimiliki. Dan melalui kegiatan program pengabdian edukasi ini dapat menjadi sebuah stimulan awal untuk membuat kajian pendidikan lingkungan hidup bagi siswa RA yang dapat didiskusikan dengan ikatan guru - guru RA diwilayah kota/kabupaten Bandung.

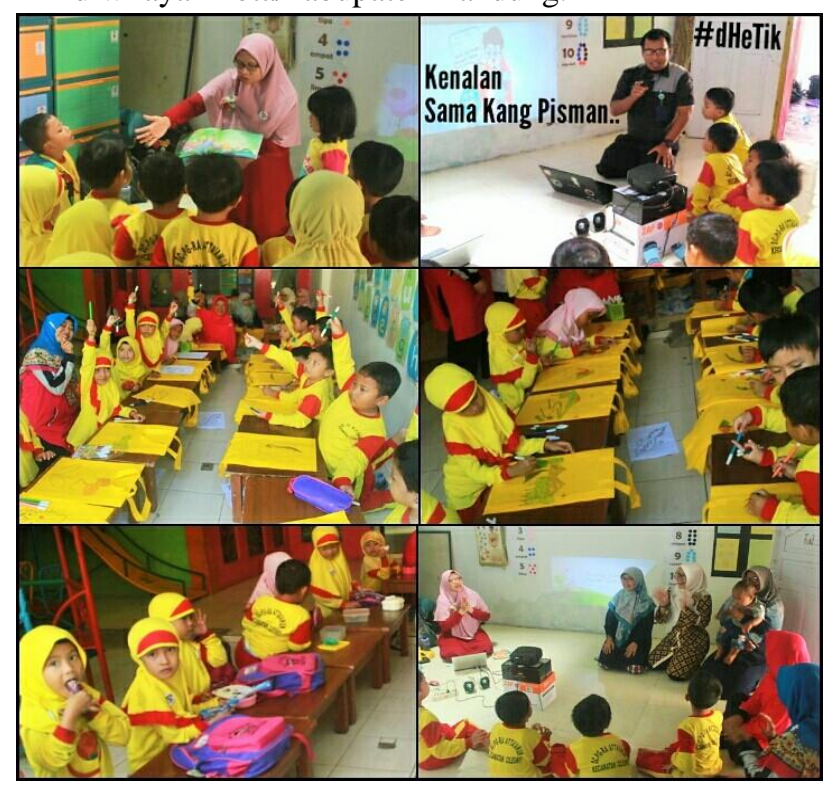

Gambar 2. Dokuemntasi Kegiatan
Telah dilaksanakan kegiatan Edukasi Lingkungan Hidup Bagi Siswa Rhaudhatul Thhfal (RA) Melalui Kegiatan Menggambar Totebag Sebagai Upaya Meminimalisir Penggunaan Plastik di RA Atta'awun Komplek Pilar Biru Kabupaten bandung. Kegiatan ini dilaksanakan dengan acara tatap muka penyampaian materi, story telling, pemutaran video, bermain mewarnai totebag dan makan snack bersama dengan penanaman budaya "zero waste" dengan membawa tempat makan dan minum sendiri. Secara garis besar kegiatan berjalan dengan baik dan lacar. Pertemuan tatap muka dengan metode ceramah, story telling dan demonstrasi menggunakan video melalu media laptop dan infokus yang difasilitasi oleh sekolah. Kegiatan ini dilaksanakan sehari yaitu pada hari Jumat tanggal 29 Maret 2019 dari pukul 08.00 - 11.00 WIB. Peserta kegiatan berjumlah 18 orang siswa yang merupakan siswa - siswi Ra Atta'awun kelas A dan B Usia 5 - 6 Tahun. Lokasi Penyelenggaraan Kegiatan Pengabdian ini dilaksanakan di RA Atta'awun Komplek pilar biru jalan pilar barat no.15 Rt.02 / Rw 12 Desa Cibiru Hilir Kecamatan cileunyi Kabupaten Bandung. Adapun yang menjadi pemateri edukasi pengurangan sampah plastik untuk siswa RA adalah Ibu Astri Yuliawati, M.Si yang merupakan dosen pendidikan biologi FTK UIN SGD Bandung ; sedangkan untuk kegiatan bermain dalam edukasi sampah plastik dengan kegiatan mewarnai totebag difasilitasi oleh ibu Sri Maryanti, S.Si., M.Pd yang merupakan Dosen Pendidikan Biologi Fakultas tarbiyah dan keguruan UIN Sunan Gunung Djati Bandung. Secara keseluruhan kegiatan ini di ketuai oleh Bapak Dr. Dede Trie Kurniawan, S.Si., M.Pd selaku dosen PGSD FKIP Universitas swadaya gunung Jati Cirebon.

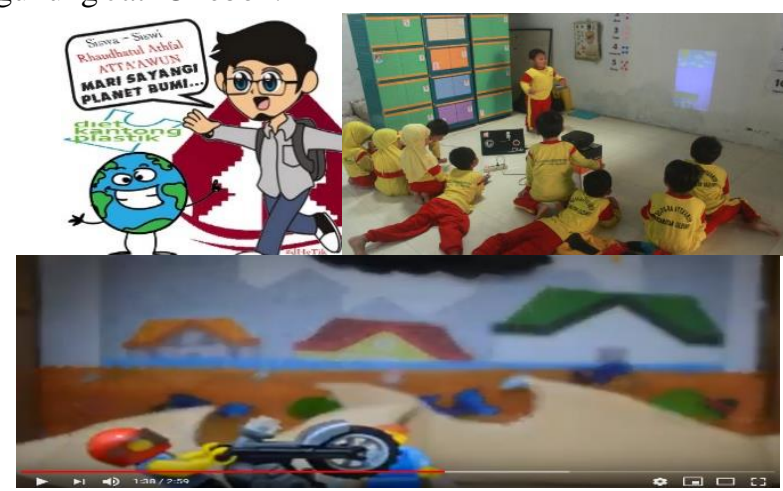

Gambar 3. Dokuemntasi Kegiatan menonoton Film Animasi Pendidikan Lingkungan Hidup Yang dikembangkan.

Sumber Video :

https://www.youtube.com/watch?v=Uw2KhEbwsvo\&feat $\underline{\text { ure }=\text { youtu.be }}$

Pelaksanaan kegiatan Edukasi Lingkungan Hidup Bagi Siswa Rhaudhatul Thhfal (RA) Melalui Kegiatan Menggambar Totebag Sebagai Upaya Meminimalisir 
Penggunaan Plastik di RA Atta'awun Komplek Pilar Biru Kabupaten bandung ini dilakukan 2 (dua) orang tim pemateri dengan pokok bahsan yang disampaikan mengenai : Pengurnagan sampah plastik dengan Budaya Kanh Pisman, dan bermain mewarnai totebag sebagai upaya pengurangan sampah plastik, Diskusi tanya jawab, Pengisian Lembar Evaluasi pelaksanaan kegiatan oleh pengelola sekolah, dan Ramah - tamah dan foto bersama. Semua Kegiatan dapat terlaksanan kegiatan baik dan lancar berkat dukungan dan bantuan semua pihak baik sekolah maupun kampus.

Kegiatan yang diawali dengan perkenalan pemateri dan penyampaian maksud dan tujuan diselenggarakannya kegiatan Edukasi Lingkungan Hidup Bagi Siswa Rhaudhatul Thhfal (RA) Melalui Kegiatan Menggambar Totebag Sebagai Upaya Meminimalisir Penggunaan Plastik di RA Atta'awun Komplek Pilar Biru Kabupaten bandung. Dari Kegiatan ini, dapat diketahui bahwa pada umumnya siswa antusias dan baru mengetahui mengenai bahaya sampah plastik bagi bumi dan bagaimana cara mengurangi sampah plastik yang ada. Acara kemudian dilanjutkan dengan sesi tanya jawab. Secara Garis Besar Inti pertanyaan siswa adalah : bencana yang dihadapai bila masalah sampah tidak ditangani dengan benar, seperti banjir dan mengapa sampah bisa mengalir sampai kelaut, dan Diskusi Tindak Lanjut Kegiatan Tindak Lanjut kegiatan kepada siswa agar bagaimana mengurangi penggunaan sampah plastik yang ada.

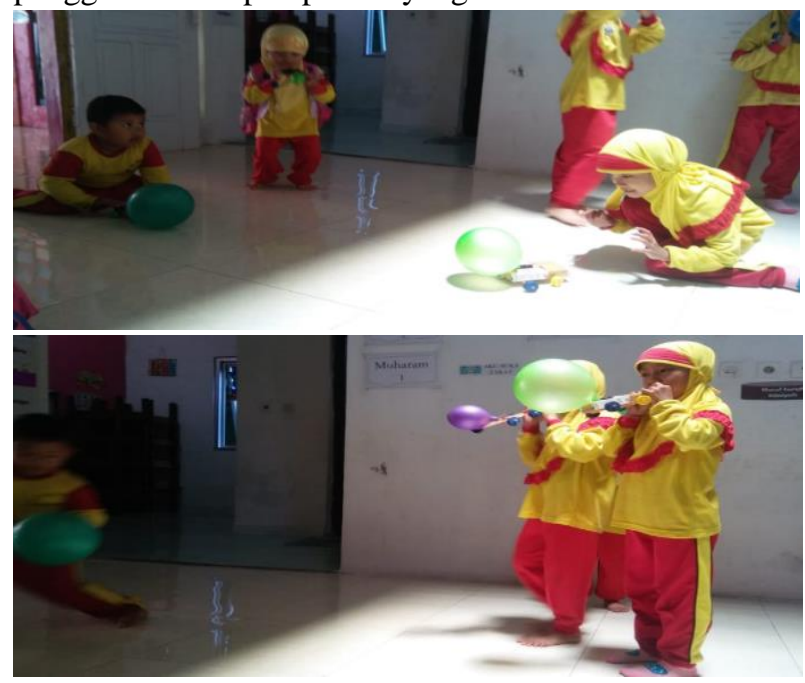

Gambar 4. Dokumentasi Kegiatan Siswa Berkreasi dan memanfaatkan sampah bekas untuk membuat permainan Mobil roket balon

\section{Ucapan Terima Kasih}

Penulis mengucapkan terima kasih kepada berbagai pihak yang telah membantu dalam penulisan makalah ini. Makalah ini didanai oleh Program Pengabdian Kepada Masyarakat Lembaga Pengabdian Kepada Masyarakat Universitas Swadaya Gunung Jati Tahun 2019

\section{PENUTUP}

\section{Kesimpulan}

Secara Garis besar Pelaksanaakan kegiatan Edukasi Lingkungan Hidup Bagi Siswa Rhaudhatul Thhfal (RA) Melalui Kegiatan Menggambar Totebag Sebagai Upaya Meminimalisir Penggunaan Plastik di RA Atta'awun Komplek Pilar Biru Kabupaten bandung dapat dikategorikan sukses dan berjalan dengan baik. Hal ini dapat ditunjukan dengan sebagian besar pemberian respon dari peserta siswa RA, Guru dan Kepala sekolah RA yang mengungkapkan bahwa kegiatan ini sangat baik karena dapat memberikan manfaat dan memperluas wawasan mereka selaku anggota masyarakat yang di lingkungan mereka terkenal selalu rawan kejadian banjir akibat penanganan sampah plastik yang tidak baik.

\section{Saran}

Berdasarkan hasil dan temuan pelaksamaan kegiatan, diajukan beberapa rekomendasi sebagai berikut:

1. Meluaskan Objek Pengabdian Ke siswa Sekolah dasar dengan mengadakan kegiatan memperingati Hari Bumi setiap tanggal 22 April

2. Menyediakan / Menambah fasilitas Tempat sampah untuk memilah sampah organik dan anorganik di sekolah

3. Menggiatkan dan mengusulkan program Bank sampah untuk disekolah yang menjadi objek pengabdian.

\section{DAFTAR PUSTAKA}

Adiwijaya, M., 2008. Peran Pemerintah, Industri Ritel, dan Masyarakat dalam Membatasi Penggunaan Kantong Plastik Sebagai Upaya Pelestarian Lingkungan. Indonesia. Fakultas Ekonomi Universitas Kristen Petra.

Asih, Novi Tri.2018. Pengelolaan Sampah Disekolah (Studi Tentang pembentukan karakter Peduli Lingkungan di SD Negeri 3 Bancarkembar Kabupaten Banyumas). Skripsi. Jurusan PAI FTK IAIN Purwokerto.

Billah, Muhammad Naufal Mu'tahsim.2013. Diet Kantong Plastik, Dari Kantong plastik Ke Tas Ramah Lingkungan. Jurusan Administrasi Publik. FISIP UNDIP Semarang.

Choirul Amri dan Wahyu Widyantoro. (2017). Pendampingan Pembelajaran Memilah Dan Menempatkan Sampah Pada Tempatnya Sejak Usia Dini Di TK Imbas 1. International Journalof Community Service Learning. Vol.1 (3) pp. 121-126.

Dani Sucipto, Cecep. 2012. Teknologi Pengolahan Daur Ulang Sampah. Yogyakarta: Gosyen Publishing. 
Program Edukasi Lingkungan Hidup Bagi Siswa RA Untuk Memahamkan Konsep “Kang Pisman” Melalui Kegiatan Bermain

Dwiyatmo, Kus. 2007. Pencemaran Lingkungan dan Penanganannya. Yogyakarta: PT. Citra Aji Parama.

Gunarsa, S. . (2004). Psikologi Praktis: Anak, Remaja, dan Keluarga. Jakarta: Gunung Mulia.

Nasih, W. . (2010). Pengelolaan Sampah yang Ramah Lingkungan di Sekolah, Pelatihan Pengembangan Sekolah Hijau untuk guru-guru SMK RSBI se-DIY. LPPM UGM bekerja sama dengan Dinas Pendidikan, Pemuda dan Olah Raga Provinsi DIY.

Wibisono, Clarry Hugh., 2011. Sosialisasi Gaya Hidup Cermat Menggunakan Kantong Plastik Melalui Kampanye Cemerlang. Fakultas Seni Rupa Dan Desain Universitas Kristen Maranatha.

Wintoko, Bambang. 2012. Panduan Praktis Mendirikan Bank Sampah Keuntungan Ganda Lingkungan Bersih dan Kemapanan Finansial. Yogyakarta: Pustaka Baru Press. 